\title{
CORPORATE SOCIAL RESPONSIBILITY AS A CHANCE FOR SUSTAINABLE SOCIAL-ECONOMIC DEVELOPMENT OF SMALL AND MEDIUM ENTERPRISES IN POLAND AND LATVIA
}

\author{
Dagmara K. Zuzek ${ }^{1}$, PhD; Andra Zvirbule ${ }^{2}$, Dr.oec. \\ 1,2 Agricultural University in Cracow, Faculty of Economics, Department of Economics and Economic Policy \\ Latvia University of Life Sciences and Technologies, Faculty of Economics and Social Development
}

\begin{abstract}
In scientific literature, one can come across different approaches to the idea of corporate social responsibility (CSR). It is mainly due to the fact that individual dimensions of this phenomenon are very broad. Most studies of CSR focus on larger organizations, thus there are only few studies focusing on small and medium enterprises (SMEs). Therefore, there is a need to adapt the principles and instruments of corporate social responsibility to the specificity of the sector of small and medium enterprises, which is of great importance for the development of economies all over the world.

The main goal of this paper is to describe the meaning of actions within CSR in the SME sector, both in Poland and in Latvia, taking into account the possibility of carrying them out and barriers in implementing them. The tasks of the research: 1) to explore the main areas of CSR which relate to SMEs and sustainable socioeconomics development; 2) to observe and analyse CSR main areas for SMEs in Poland and Latvia; 3 ) to make conclusions about CSR importance for SMEs in sustainable development.
\end{abstract}

Keywords: corporate social responsibility, small and medium enterprises, sustainable development. JEL code: O44; Q01; R11

\section{Introduction}

Activities of small and medium enterprises and also the objectives they pursue are more and more frequently determined by the idea of sustainability. This stems from their desire for responsibility to the environment they operate in. Greater awareness of entrepreneurs in noticing problems associated with their impact on their environment contributes to these aspects being taken into account at the stage of building a strategy or a relationship with different groups of stakeholders. Adoption of such an attitude is defined as the concept of corporate social responsibility and is one of the most modern and promising business strategies (Sikorska, 2010).

Source literature on the concept of CSR indicates that there is a great interest, mainly among big enterprises, in such activities. Therefore, there is a need to adapt the principles and instruments of corporate social responsibility to the specificity of the sector of small and medium enterprises, which is of great importance for the development of economies all over the world (Emonitor, 2009).

The main goal of this paper is to describe the meaning of actions within CSR in the SME sector, both in Poland and in Latvia, taking into account the possibility of carrying them out and barriers in implementing them. The tasks of the research: 1 ) to explore the main areas of CSR which relate to SMEs and sustainable socio-economics development; 2) to observe and analyse CSR main areas for SMEs in Poland and Latvia; 3) to make conclusions about CSR importance for SMEs in sustainable development.

Research methods: logical construction, analysis and synthesis, the graphic and monographic methods and in-depth expert interviews.

\section{Research results and discussion}

\section{Theoretical approach to corporate social responsibility}

In scientific literature one can come across different approaches to the idea of corporate social responsibility (CSR). It is mainly due to the fact that individual dimensions of this phenomenon are very broad (Wasowska, Pawlowski, 2011). The idea of the concept is to promote actions, taking 
into account social conditions in which the enterprise operates. This phenomenon applies to economy, society and adopted values, and also to the relations with the surrounding environment. It includes the interests of consumers, local communities and the natural environment (www.mg.gov.pl/\# les/upload/7904/podrecznik.pdf.).

The beginning of realizing the idea of CSR results from the concept of sustainable development, according to which not only the economic but also the social and environmental aspects are important in economic development. It should be emphasized that "social commitment allows the pursuit to maintain balance between the economic, ecological and social aspects in corporate activities, which contributes to accomplishment of goals which are attributed to sustainable developmental (protection of natural resources, maintaining stability of ecosystems, improvement of human health and of general well-being) (Bogdanienko, 2011).

The need for the development of the aforementioned concept stems not only from the enterprises themselves, but also from the local community, competition, local and central authorities and many other participants of socio-economic life, having an indirect or direct impact on business entities (Zuzek, 2012).

Corporate social responsibility is often described as a moral and lawful obligation towards the whole environment (both internal and external), which surrounds each enterprise (Zbiegan-Maciag, 1997). In other words, it is a certain sensitivity to the issues of the external environment, including social or ecological sensitivity and the ability to maintain equilibrium between the interests of customers, employees and stockholders, as well as providing certain services for the local community (Zemigala 2007). Therefore, it is a strategy of competitive advantage based on providing a lasting value to stakeholders (Gaspsrski, Lewicka-Strzalecka, Rok, Szulczewski, 2004). This approach is a new tendency of changes in sustainable development, with observance of the principles of economics, ecology and ethics (Korpus, 2006).

Due to its multifaceted approach, the CSR concept is the responsibility for the liabilities that is taken by an enterprise as a result of its functioning in the society (Adamczyk, 2009). S. Young (2005) has a similar view on this phenomenon, believing that it is a strategic and long-term approach based on the principles of social dialogue, transparent relations and looking for beneficial solutions for all economic entities. Implementation of the indicated tasks should take into account not only ethical or legal values, but also respect for employees, society and the natural environment, in order to improve the life quality of all citizens.

\section{Key areas of corporate social responsibility}

In scientific literature, one can find several areas of interest to social responsibility. The most common one is the classification according to the objective-subjective criterion. It allows to distinguish the following types of responsibilities (Paliwoda-Matiolanska 2009):

- economic - associated with maximization of profits, minimization of costs, making strategic decisions or executing the policy of dividing the profits, and creating competitiveness,

- legal - arising from observing the law, environmental protection regulations and consumer rights, counteracting corruption, fulfilling all contract obligations,

- ethical - eliminating undesirable behaviours, treating law as an unconditional minimum and taking actions exceeding this minimum, ethical leadership, actions compliant with social expectations, 
- philanthropic - care for the improvement of social life quality, commitment in voluntary work, charity activity, and also commitment to local communities.

D. Aarts (2011) also distinguishes four main areas of corporate social responsibility: workplace, natural environment, community, and market. More and more entrepreneurs recognize that employees want to work in companies that not only offer interesting and financially attractive workplace, but also care about the state of the natural environment and try to contribute to the fight against global challenges.

Small and medium enterprises more concentrate, to preserve the culture and personal values, the reputation and the recognition of their customers, and keep the more responsibility about the local social-economic environment sustainability (P.Castejon, B. Lopez, 2016).

Some authors have highlighted the recent drastic socioeconomic and political changes, beyond a CSR management of externalities and towards a value creation for the common good.

\section{National corporate responsibility index - country scores}

\begin{tabular}{|l|c|c|}
\hline No in rating & Country & NCSRI \\
\hline \multicolumn{2}{|c|}{ Countries with high corporate responsibility index } \\
\hline 1. & Switzerland & 20.64 \\
\hline 2. & Sweden & 19.50 \\
\hline 3. & Finland & 18.99 \\
\hline Countries with medium high corporate responsibility index \\
\hline 22. & Brazil & -11.74 \\
\hline 23. & Colombia & -11.99 \\
\hline 24. & South Korea & -12.13 \\
\hline Countries with moderate low corporate responsibility index \\
\hline 46. & Latvia & -24.81 \\
\hline 47. & Indonesia & -25.03 \\
\hline 48. & Estonia & -25.12 \\
\hline 55. & Poland & -26.36 \\
\hline \multicolumn{2}{|c|}{ Countries with low corporate responsibility index } \\
\hline 75. & Ukraine & -31.66 \\
\hline 76. & Georgia & -32.26 \\
\hline 77. & Russian Federation & -32.38 \\
\hline
\end{tabular}

Source: Skouloudis et al., 2016

In this context, a growing number of companies are shaping CSR strategies to stimulate innovation and differentiate themselves from peers. NCSRI was selected as it signifies the first CSR-specific index to rank a considerable sample of countries around the world according to CSR penetration and endorsement in line with related global standards and initiatives. It shows the level of country in global CSR.

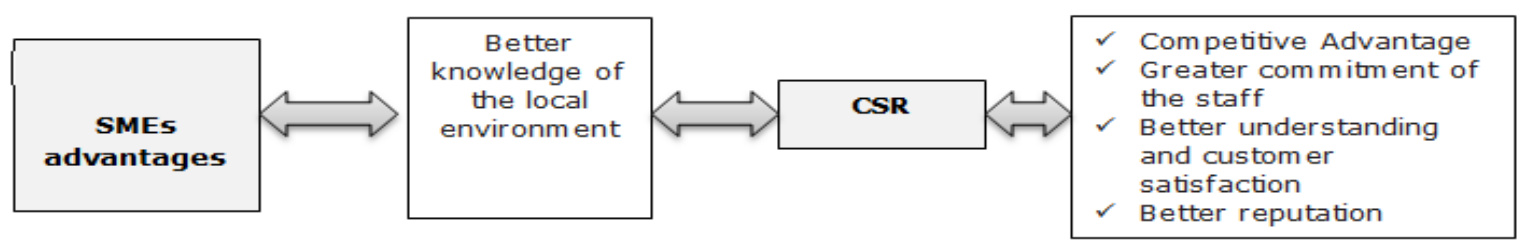

Source: author's compilation based on P.Castejon, B. Lopez 2016

Fig. 1 Linkage between advantages and benefits of CSR in SMEs

As shown in Fig. 1. SMEs are the main factor in creation of wealth and the basic engine of the regional/ local economy. They represent a commitment to their territorial/local community through 
continuity, which is demonstrated by a higher degree of investment and even employment together with social responsibility. As a main focusing in this case is better understanding and customer satisfaction in local area. These theoretical and practical assumptions provide a basis for sustainability and interaction for corporate social responsibility.

\section{Possibilities of fulfilling the assumptions of CSR and benefits obtained by enterprises}

Development of the concept of social responsibility does not refer only to large enterprises. One can notice numerous initiatives to popularize this phenomenon also in small and medium enterprises which are a dominant part of enterprises in economy. In Poland, this sector covers $99.9 \%$ of all operational entities, $99.2 \%$ of which are small entities (including $96.0 \%$ micro) (www.stat.gov.pl). Small enterprises are of great economic importance, and social importance for the economy because they are, among other things, a source of workplaces, alleviate the effects of mass layoffs in large enterprises, quickly react to changes in consumers' consumption attitudes, adapt to the market, and quickly eliminate supply gaps (Sipa, 2010).

Enterprises from the SME sector are also characterized by a range of specific quality features thanks to which they can aspire to be recognized as socially responsible enterprises. These features include (Sipa, 2010):

1) dominant role of the owner in the company's management,

2) development of structural external relational capital, connected with building good relations with stakeholders (especially the ones from the closest environment),

3) dynamism, flexibility, and openness of the business model,

4) quick reaction to changes taking place in the environment and the possibility of reacting quickly to internal problems (close contact with employees).

In small and medium enterprises, despite the existence of many features that favour implementation of the concept of social responsibility, actions taken by them in this scope are still limited. Entrepreneurs are often faced with choices associated with rational management (Sitek, 2009). This causes occurrence of divergences in achieving economic and social objectives. Another problem is lack of models of socially responsible actions for this type of enterprises. It is not always appropriate to imitate the actions taken by large companies because most of them implement the concept of CSR thinking about promoting their business. It should also be highlighted that taking actions within corporate social responsibility by the SME sector depends mostly on the owners, their skills and experience, and in particular their system of values.

Using the concept of corporate social responsibility is beneficial not only for a given company, but also for the whole society. Strategic approach to the concept of CSR is gaining importance in competitiveness of enterprises. Entrepreneurs usually point to benefits from implementing such an approach. This mainly refers to the improvement of the image, savings, the possibility to stand out, increased interest of investor, lifting employees' morale, and reducing the risk of the business (Kroik, Malara, 2011). The following benefits for socially responsible enterprises can be distinguished (Ocieczak, Gajdzik, Kuczynska-Chalada, 2011):

- enhancement of the corporate image,

- building a new reputation as a socially responsible enterprise,

- creating new business possibilities (new markets, innovations, better technical solutions etc.),

- ensuring stabilization and understanding in the environment, 
- increased attractiveness of an enterprise as employer (socially responsible business takes care of employees' development),

- increased work efficiency through improvement and rationalization of processes,

- a synergy effect in the company and in the environment as a result of intensive communication within the company and with different social groups.

The results of the conducted research with respect to understanding the notion of corporate social responsibility indicate that more than $70 \%$ of large enterprises are familiar with this idea. In the case of the sector of small and medium enterprises, $50 \%$ of medium enterprises, $36 \%$ of small enterprises and $26 \%$ of micro-enterprises declared knowledge of this notion (Fig. 2).

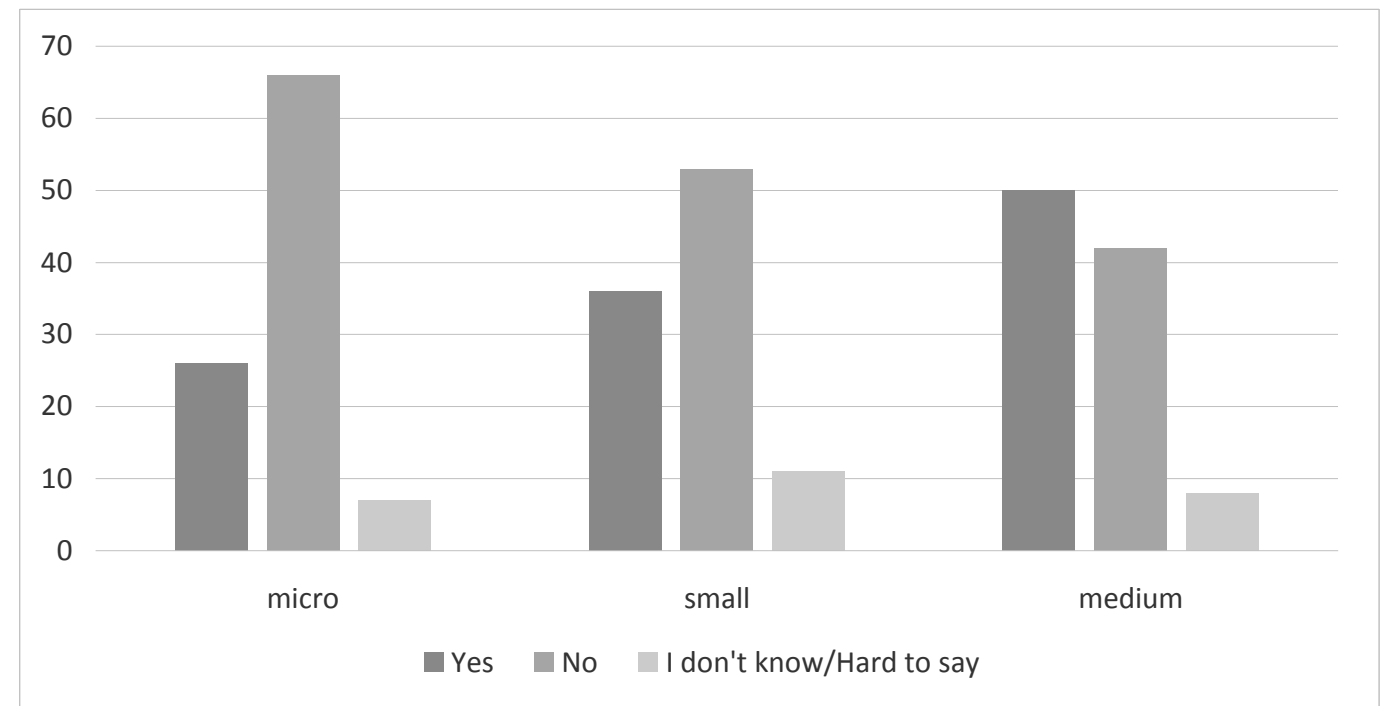

Source: Assessment of the status of implementation of CSR standards. A set of indices of social responsibility in micro, small, medium and large enterprises. Report (2011), MillwardBrown SMG/KRC, PwC for PARP, Warszawa

Fig. 2 Knowledge of the concept of CSR in Poland with respect to the size of the enterprise

Each enterprise has a direct or indirect impact on the environment it functions in. This requires responsible actions not only from you but also from your suppliers, not only in the economic aspect but also the social and environmental one. That is why it is surprising that only $37 \%$ of the studied entities assess their business partners' compliance with the principles of business ethics understood as abiding by agreements, ensuring equality between parties, paying the amount due on time, handling complaints professionally etc. Less than $20 \%$ of enterprises assess their suppliers in terms of their relations with employees and compliance with work safety regulations. As many as $40 \%$ of companies do not assess their business partners in terms of the actions they take within the scope of corporate social responsibility at all (Fig. 3).

The studied enterprises were convinced that actions taken within the scope of CSR are sufficient. More than $50 \%$ of respondents were of this opinion. The areas of CSR into which the studied entities were planning to increase their commitment in the perspective of the next few years included a change in enterprise organization as well as improvement of relations with employees and business partners. 


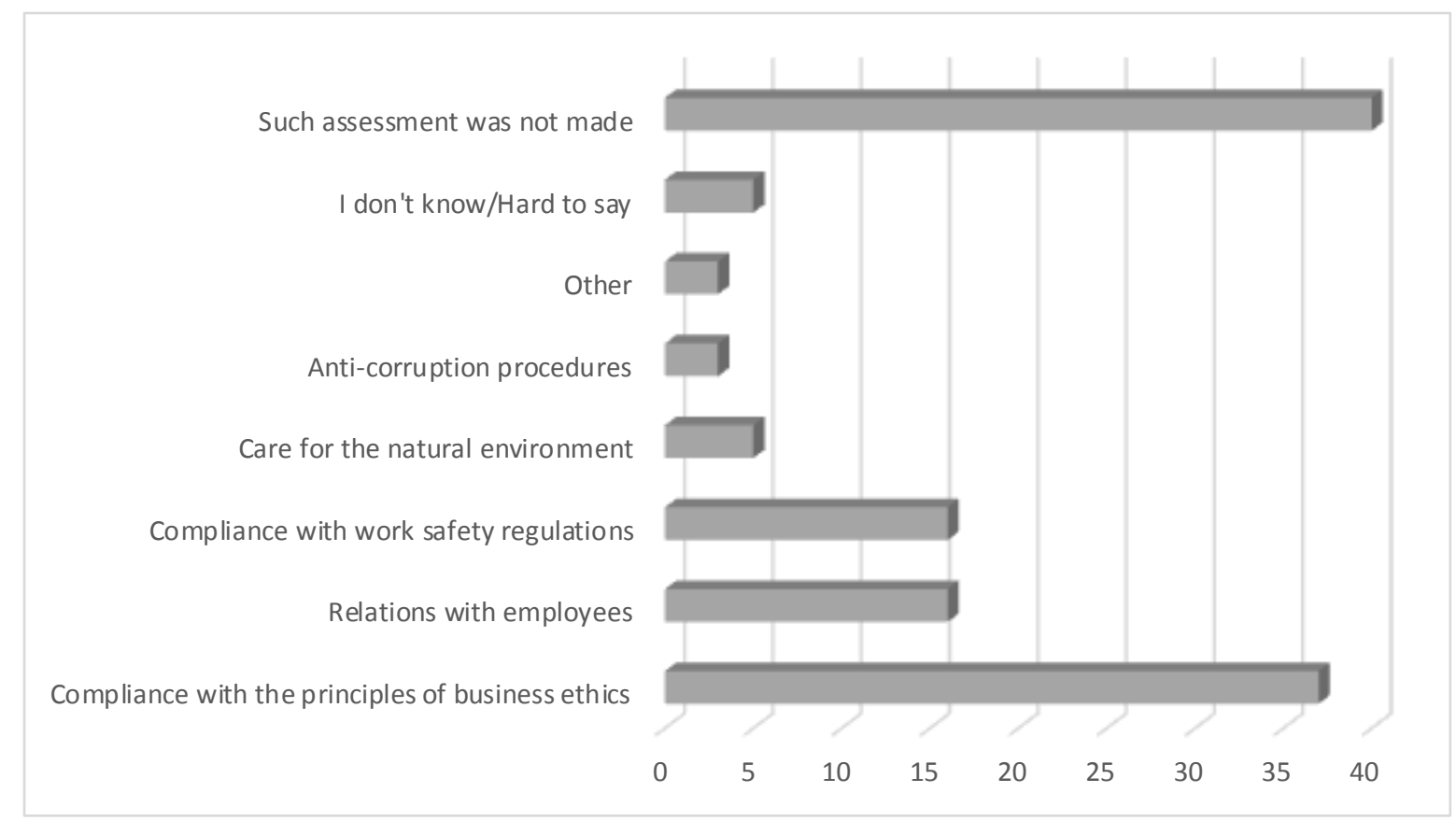

Source: Assessment of the status of implementation of CSR standards. A set of indices of social responsibility in micro, small, medium and large enterprises. Report (2011), MillwardBrown SMG/KRC, PWC for PARP, Warszawa

\section{Fig. 3 Assessment of suppliers and business partners in areas concerning CSR}

In Latvia case, authors conducted in-depth expert interviews with SMEs owners in Zemgale region $(n=30)$. Business owners noted in their interviews that at the initial stage of their company's operations they had encountered some problems to establish CSR standards in company:

- selection of the team, its motivation and guidance;

- availability of skilled workers;

- lack of professional specialized knowledge;

- attracting customers and ensuring the stability of working with them;

- providing high-quality service for customers

- lack of working capital;

- bureaucratic problems;

- the right choice of premises for the implementation of the business.

In addition, they enthusiastically built and provided stable communication networks with suppliers and customers offering non-standard ways of attracting them. In order to solve the issue of increasing working capital for business development, entrepreneurs developed more efficient schemes for running their business, worked actively with the banking and financial sectors, participated in financing programs for young businessmen, and also attracted money from their relatives and friends. All interviewees noted that the problems had a positive impact on the company's development and building up CRS. They taught to work with people, to get new knowledge and experience, to actively cooperate with suppliers, clients and colleagues, to improve the quality of products and services, to search for new markets for the realization of their products, to look for alternative ways of business development, to assess additional directions, constantly think about the development of the company. 


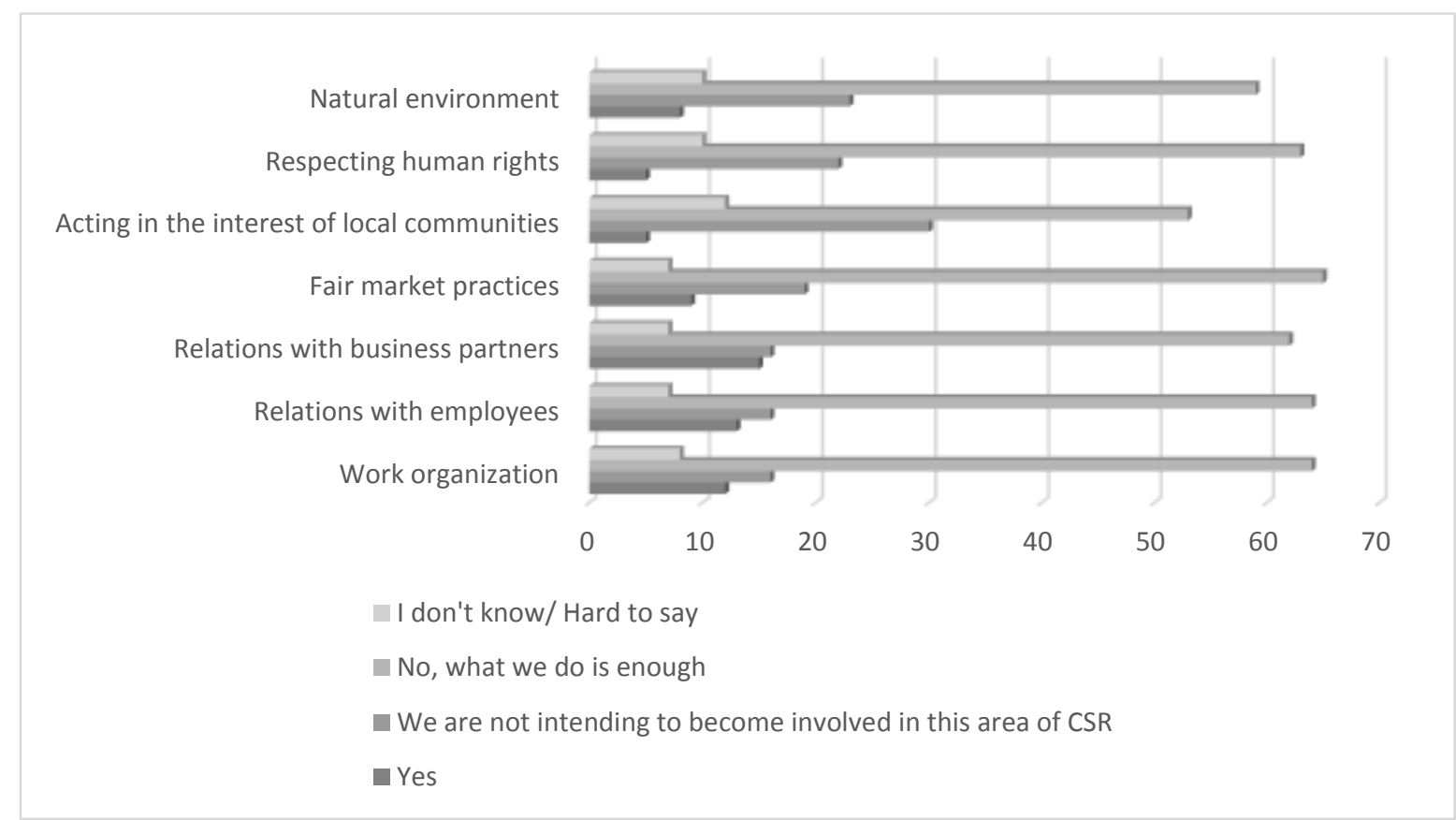

Source: Assessment of the status of implementation of CSR standards. A set of indices of social responsibility in micro, small, medium and large enterprises. Report (2011), MillwardBrown SMG/KRC, PwC for PARP, Warszawa Fig. 4 Areas where enterprises intend to increase their commitment to CSR in Poland

As shown in Fig. 4, the percentage of enterprises which see the need to increase commitment in some areas ranged between $12 \%$ and $15 \%$. As many as $30 \%$ companies declare that they are not intending to become involved in activities in the interest of the local community, and over $1 / 5$ in activities benefitting environmental protection. The entrepreneurs' declaration that they are not planning to take new actions in individual areas of CSR, while earlier indicating they have little knowledge of the subject of corporate social responsibility, indicates that lack of awareness in this matter is the cause of such state of things. Such an attitude confirms the need to popularize the idea of socially responsible business and wide-ranging trainings as well as supporting programs.

\section{Conclusions, proposals, recommendations}

1) The idea of corporate social responsibility, thanks to the systems approach to creating values with taking into account social and ecological aspects is a tool for supporting business in adapting to the challenges of the current economy. To make a profit, an enterprise must not only build a value for stakeholders, but also earn their customers' loyalty, increase the effectiveness of their business, and simultaneously minimize costs and be innovative.

2) Popularization of the idea of CSR is extremely important with respect to pro-environmental solutions used. These solutions are not only more and more affordable for small and medium companies, but it pays off to implement them.

3) Theoretical and practical assumptions about SMEs role in local environment and advantages from CRS provide a basis for sustainable social-economic development.

4) In Poland, $50 \%$ of medium enterprises, $36 \%$ of small enterprises and $26 \%$ of microenterprises declared knowledge about concept of CSR

5) In Poland, $40 \%$ of companies do not assess their business partners in terms of the actions they take within the scope of corporate social responsibility at all.

6) In Latvia case, SMEs business owners noted in their interviews that at the initial stage of their company's operations they had encountered some problems to establish CSR standards in 
company: selection of the team, its motivation and guidance; lack of professional specialized knowledge; attracting customers and ensuring the stability of working with them;

7) In Latvia case, all interviewees $(n=30)$ noted that the problems had made a positive impact on the company's development and building up CRS.

\section{Acknowledgement}

The publication was financed from subsidies for maintenance of research potential granted by Ministry of Science and Higher Education

\section{Bibliography}

1. Adamczyk, J. (2009), Spoleczna odpowiedzialnosc przedsiębiorstw (Corporate Social Responsibility). PWE, Warszawa, pp. 43

2. Aarts, D. (2011), Społeczna odpowiedzialność przedsiębiorstw (Corporate Social Responsibility), (w:) Sztuka public relations. $Z$ doświadczeń polskich praktyków (The Art of Public Relations. Experiences of Polish Practitioners), Wyd. II poszerzone, Związek Firm Public Relations, Warszawa, pp. 207-210

3. Bogdanienko, J. (2011), Odpowiedzialność społeczna a strategia organizacji (Social Responsibility and Organisational Strategy), (w:) Biernatt M., Bogdanienka J., Skoczny T. (red.), Społeczna odpowiedzialność biznesu. Krytyczna analiza (Corporate Social Responsibility. Critical Analysis), Wydawnictwo Naukowe Wydziału Zarządzania Uniwersytetu Warszawskiego, Warszawa, pp. 23-25

4. Castejón, P., López B. (2016) Corporate sScial Responsibility in Family SMEs European Journal of Family Business (2016) 6, pp. 21-31

5. "E-mentor" 2009, no 5 (32), http://www.e-mentor.edu.pl/artykul/index/numer/32/id/691 [05.10.2017].

6. Gasiński, T., Piskalski, G. Zrównoważony biznes. Podręcznik dla małych i średnich przedsiębiorstw (Sustainable business. Handbook for Small and Medium Enterprises), http://www.mg.gov.pl/\# les/upload/7904/podrecznik.pdf., p. 3.

7. Gasparski, W., Lewicka-Strzałecka, A., Rok, B., Szulczewski, G. (2004), Odpowiedzialność społeczna i etyka biznesu w polskim życiu gospodarczym (Corporate Social Responsibility and Ethics in Polish Economic Life), Wydawnictwo IFIS PAN, Warszawa 2004, pp. 18.

8. Korpus, J. (2006), Społeczna odpowiedzialność przedsiębiorstw w obszarze kształtowania środowiska pracy (Corporate Social Responsibility in Shaping the Work Environment), Wydawnictwo Placet, Warszawa, pp. 84.

9. Kroik, J., Malara, Z. (2011). CSR i zrównoważony rozwój w warunkach silnej konkurencji (CSR and Sustainable Development under Strong Competition Conditions). w: Zeszyty Naukowe XXV, red. J. Kroik, Z. Malara, J. Gołota, Ostrołęckie Towarzystwo Naukowe im. Adama Chętnika, Ostrołęka, pp. 424.

10. Ocena stanu wdrażania standardów społecznej odpowiedzialności biznesu. Zestaw wskaźników społecznej odpowiedzialności w mikro, małych, średnich oraz dużych przedsiębiorstwach (Assessment of the status of implementation of CSR standards. A set of indices of social responsibility in micro, small, medium and large enterprises). Raport (2011), MillwardBrown SMG/KRC, PwC dla PARP, Warszawa.

11. Ocieczek, W., Gajdzik, B., Kuczyńska-Chałada, M. (2011). Corporate Social responsibility in steelworks, w: Zarządzanie wartością przedsiębiorstw (Enterprise Value Management), red. M. Jabłoński, Wyższa Szkoła Biznesu, Dąbrowa Górnicza, pp. 333-334.

12. Poliwoda-Matiolańska, A. (2009). Odpowiedzialność społeczna w procesie zarządzania przedsiębiorstwem (Corporate Social Responsibility in the Process of Business Management). C.H. Beck, Warszawa, pp. 67-68

13. Sikorska M. (2010). CSR w Polsce. Forum UNDP. Zarzadzanie zasobami ludzkimi (CSR in Poland: UNDP Forum. Human Resource Management) [w:] J. Kochanowicz, M. Marody (red.), Kultura i gospodarka (Culture and Economy), Wydawnictwo Naukowe Scholar, Warszawa, pp. 143.

14. Sipa, M. (2010). Czynniki wpływające na zwiększanie obszaru działalności małych przedsiębiorstw (Factors Expanding The Area Of Operation Of Small Enterprises). [w:] J. Wnuk, J. Ryśnik (red.), Współczesne koncepcje i strategie zarządzania. Teoria a praktyka (Theory and Practice). Wyższa Szkoła EkonomicznoHumanistyczna, Bielsko-Biała, pp. 43-65.

15. Sitek, M. (2009). Wpływ wybranych czynników na rozwój małych i średnich przedsiębiorstw w Polsce (Influence of Selected Factors on the Development of Small and Medium Enterprises in Poland). [W:] M. Okręglicka, O. Ławińska (red.), Determinanty rozwoju małych i średnich przedsiębiorstw w Polsce (Determinants of the Development of Small and Medium Enterprises in Poland). Wydawnictwo Politechniki Częstochowskiej, Częstochowa, pp. 157-173.

16. Skouloudis, A., Isaac, D., Evaggelinos, K., (2016) Revisiting the national corporate social responsibility index. Int. J. Sustain. Dev. World Ecol. 23 (1), pp. 61-70.

17. Wąsowska, A., Pawłowski, M. (2011). Metody pomiaru społecznej odpowiedzialności biznesu - przegląd literatury (Methods for Measuring Corporate Social Responsibility - Literature Review). „Przegląd Organizacji", no 11 , p. 14-17.

18. www.stat.gov.pl

19. Young, S. (2005), Etyczny kapitalizm. Jak na powrót połączyć prywatny interes z dobrem publicznym (Ethical Capitalism. How to Reconcile Private Interest with Public Good). Metamorfoza, Wrocław, pp. 75 
20. Zbiegień-Maciąg, L. (1997). Etyka w zarządzaniu (Ethics In Management). CiM, Warszawa 1997, pp. 48.

21. Zuzek, D. (2012). Spoleczna odpowiedzialnosc biznesu a zrównowazony rozwoj przedsiebiorstw (Corporate Social Responsibility and Sustainable Development of Companies). Tarnow: Zeszyty Naukowe Malopolskiej Wyzszej Szkoly Ekonomicznej w Tarnowie, vol. 21, No. 2.

22. Żemigała ,M. (2007), Społeczna odpowiedzialność przedsiębiorstwa. Budowanie zdrowej, efektywnej organizacji (Corporate Social Responsibility. Building a Healthy, Effective Organization), Wydawnictwo Wolters Kluwer, Kraków, pp. 99. 